\title{
BSA Degradation under Acidic Conditions: A Model for Protein Instability during Release from PLGA Delivery Systems
}

\author{
TIA ESTEY, ${ }^{1}$ JICHAO KANG, ${ }^{2}$ STEVEN P. SCHWENDEMAN, ${ }^{3}$ JOHN F. CARPENTER ${ }^{1}$ \\ ${ }^{1}$ Department of Pharmaceutical Sciences, School of Pharmacy, Center for Pharmaceutical Biotechnology, \\ University of Colorado Health Sciences Center, Denver, Colorado 80262 \\ ${ }^{2}$ Department of Formulation Development, Neose Technologies, Inc., 102 Witmer Road, Horsham, \\ Pennsylvania 19044 \\ ${ }^{3}$ Department of Pharmaceutical Sciences, University of Michigan, Ann Arbor, Michigan 48109
}

Received 7 November 2005; revised 5 February 2006; accepted 27 February 2006

Published online in Wiley InterScience (www.interscience.wiley.com). DOI 10.1002/jps.20625

\begin{abstract}
Acidification of the internal poly(lactide-co-glycolide) (PLGA) microenvironment is considered one of the major protein stresses during controlled release from such delivery systems. A model protein, bovine serum albumin (BSA), was incubated at $37^{\circ} \mathrm{C}$ for 28 days to simulate the environment within the aqueous pores of PLGA during the release phase and to determine how acidic microclimate conditions affect BSA stability. Size-exclusion high performance liquid chromatography (SE-HPLC), SDSPAGE, and infrared spectroscopy were used to monitor BSA degradation. BSA was most stable at $\mathrm{pH} 7$, but rapidly degraded via aggregation and hydrolysis at $\mathrm{pH} 2$. These simulated degradation products were nearly identical to that of unreleased BSA found entrapped within PLGA 50/50 millicylinders. At pH 2, changes in BSA conformation detected by various spectroscopic techniques were consistent with acid denaturation of the protein. By contrast, at pH 5 and above, damage to BSA was insufficient to explain the instability of the protein in the polymer. Thus, these data confirm the hypothesis that acid-induced unfolding is the basis of BSA aggregation in PLGA and the acidic microclimate within PLGA is indeed a dominant stress for encapsulated BSA. To increase the stability of proteins within PLGA systems, formulations must protect against potentially extreme acidification such that native structure is maintained.

(C) 2006 Wiley-Liss, Inc. and the American Pharmacists Association J Pharm Sci 95:1626-1639, 2006

Keywords: protein stability; protein aggregation; UV/Vis spectroscopy; circular dichroism; FTIR; poly(lactide-co-glycolide) (PLGA); bovine serum albumin; aciddenaturation
\end{abstract}

Abbreviations: BSA, bovine serum albumin; PLGA, poly (lactide-co-glycolide); SE-HPLC, size-exclusion high performance liquid chromatography; FTIR, Fourier-transform infrared spectroscopy; CD, circular dichroism; UV, ultraviolet; GdnHCl, guanidine hydrochloride; PBST, phosphate-buffered saline with $0.02 \%$ Tween- 80 .

Correspondence to: John F. Carpenter (Telephone: 303-3156073; Fax: 303-315-0274; E-mail: john.carpenter@uchsc.edu)

Journal of Pharmaceutical Sciences, Vol. 95, 1626-1639 (2006)

(C) 2006 Wiley-Liss, Inc. and the American Pharmacists Association

\section{INTRODUCTION}

Recent advances in biotechnology have lead to an explosion in the production of recombinant therapeutic proteins as potential drug candidates. The development of safe and effective delivery options for these proteins, however, has not been as progressive. Currently, injection is the most common method used to deliver therapeutic proteins due 
in part to poor absorption, low bioavailability, and short in vivo half-lives through other routes of administration. ${ }^{1}$ Patients that require chronic treatment with such therapeutics are often subjected to daily injections. A controlled-release delivery system, which delivers the protein drug slowly and continuously for weeks to months, is a desirable alternative to the present standard and would improve patient compliance, comfort, and safety.

Biodegradable and biocompatible polymers, such as poly(lactide-co-glycolide) (PLGA), have gained much attention and research focus for use in the controlled release of therapeutic proteins. PLGA has been used for many years in various medical applications (i.e., surgical sutures) and the safety of the polymer is well-established. ${ }^{2-4} \mathrm{~A}$ variety of delivery systems, such as microspheres and millicylindrical implants, can be produced using PLGA, and specific release profiles may be generated through manipulating the properties of the polymer. ${ }^{5}$ PLGA has been used effectively in the controlled release of low molecular weight steroids $^{6,7}$ and peptides. ${ }^{8,9}$ By contrast, the use of PLGA in the delivery of therapeutic proteins, which are more complex than small peptides in both structure and stability, has been less successful. Nutropin Depot ${ }^{\circledR}$ (Alkermes-Genetech) is the only FDA-approved product that utilizes PLGA for the controlled release of a therapeutic protein, recombinant human growth hormone. ${ }^{10}$ However, this product is no longer marketed.

One of the greatest limitations in the development of PLGA controlled-release systems is the incomplete release and instability of the encapsulated protein. Incomplete in vitro protein release has been observed with many PLGA delivery systems and is attributed to protein instability within the PLGA device. ${ }^{1,11-13}$ Protein instability during the release phase of PLGA systems is not completely understood, though the dominant protein stresses during release are hypothesized to include (i) increased protein mobility during the hydration of the delivery system and (ii) acidification of the PLGA microclimate. ${ }^{13}$ During processing, PLGA devices are typically dried to remove organic solvents required for encapsulation. ${ }^{14}$ It is well-known that the secondary structure of proteins may be compromised during this dehydration step, leading to partially unfolded and aggregate-prone conformations. ${ }^{15,16}$ Upon rehydration, the protein must refold back to the native state and this process competes with the formation of nonnative intermolecular interactions that drive protein aggregation. As the PLGA system imbibes water, the high protein concentrations reached during rehydration of PLGA matrix should favor aggregation over refolding. Water uptake also catalyzes the erosion of the polymer via the hydrolysis of ester linkages, producing lactic and glycolic acids. ${ }^{5,17}$ These breakdown products quickly acidify the aqueous pores where encapsulated protein resides in PLGA systems ${ }^{18-20}$ and have been observed to decrease the internal system $\mathrm{pH}$ to values less than $3{ }^{19,21}$ Exposure of the protein to acidic conditions may lead to perturbations in the native structure of the protein, which in concert with high protein concentration could foster rapid aggregation.

In this study, we examined the influence of the acidic microclimate conditions on the structural stability of bovine serum albumin (BSA). BSA is a commonly used model protein for PLGA-based controlled-release studies, and BSA instability within PLGA has been well-documented. ${ }^{12,13}$ BSA degradation was examined as a function of protein concentration, buffer $\mathrm{pH}$, and buffer ionic strength during incubation for 1 month at $37^{\circ} \mathrm{C}$ to simulate the conditions that exist in PLGA delivery systems during the release phase. The degradation of the protein was characterized and compared to that observed with PLGA-encapsulated BSA. Structural analysis of BSA under the solution conditions used in this study was thoroughly performed using infrared, circular dichroism (CD), and second derivative ultraviolet (UV) absorbance spectroscopic methods to help elucidate the underlying mechanisms of instability.

\section{MATERIALS AND METHODS}

BSA (lyophilized powder, Fraction V) was purchased from Sigma and used without further purification. All chemicals were of reagent grade or higher, and obtained from Sigma unless otherwise noted.

\section{Sample Preparation and Incubation}

BSA was dissolved in $10 \mathrm{mM}$ potassium phosphate $(\mathrm{pH}$ 7.0) and dialyzed (Slide-A-Lyzer dialysis cassette, $10 \mathrm{kDa}$ MWCO, Pierce Biotechnology, Inc., Rockford, IL) against a large volume of the appropriate buffer at $4^{\circ} \mathrm{C}$. Low-ionic strength buffers contained $10 \mathrm{mM}$ potassium phosphate and $0.02 \%(\mathrm{w} / \mathrm{v})$ sodium azide, and high-ionic strength buffers contained $10 \mathrm{mM}$ 
potassium phosphate, $150 \mathrm{mM}$ sodium chloride, and $0.02 \%(\mathrm{w} / \mathrm{v})$ sodium azide. Samples were prepared at $\mathrm{pH} 2,5$, and 7 and at protein concentrations of 10,40 , and $100 \mathrm{mg} / \mathrm{mL}$ under both low- and high-ionic strength conditions. When necessary, samples were concentrated using an Amicon device equipped with a $30 \mathrm{kDa}$ MWCO membrane (Whatman, Inc., Florham Park, NJ) under $\mathrm{N}_{2}$ gas. Protein concentration was determined by $\mathrm{A}_{279}\left(\varepsilon=0.667 \mathrm{~mL} \mathrm{mg}^{-1} \mathrm{~cm}^{-1}\right.$ provided by the supplier), and samples were centrifuged $\left(20000 \mathrm{~g}\right.$ for $10 \mathrm{~min}$ at $4^{\circ} \mathrm{C}$ ) prior to measuring protein concentration. For each incubation condition, the samples were filtered $(0.2 \mu$ cellulose acetate) and aliquots $(0.2 \mathrm{~mL})$ were prepared in $0.25 \mathrm{~mL}$ PCR tubes, which were then wrapped with parafilm to prevent sample evaporation. For each solution condition and incubation time-point, triplicate sample tubes were prepared. The sample tubes were placed vertically in a rack and stored in a $37^{\circ} \mathrm{C}$ incubator.

\section{SE-HPLC}

A Hewlett-Packard 1090 HPLC ( $250 \mu \mathrm{l}$ injection syringe and diode array UV detection), equipped with a TSK-Gel 3000 SW $_{\mathrm{XL}}$ column (Tosoh Biosciences LLC, Montgomeryville, PA) was used for size-exclusion high performance liquid chromatography (SE-HPLC) analysis. The mobile phase was $10 \mathrm{mM}$ potassium phosphate, $150 \mathrm{mM}$ sodium chloride and $0.02 \%(\mathrm{w} / \mathrm{v})$ sodium azide, $\mathrm{pH} 7.0$, which was filtered $(0.2 \mu$ membrane, Whatman, Inc.) and degassed prior to use. Samples were centrifuged ( $20000 \mathrm{~g}$ for $10 \mathrm{~min}$ at $4^{\circ} \mathrm{C}$ ) to remove insoluble aggregates and diluted in mobile phase buffer prior to application to the column. The flow rate during analysis of protein samples was $0.6 \mathrm{~mL} / \mathrm{min}$, and protein was detected at $214 \mathrm{~nm}$. To quantitate loss in BSA monomer, chromatograms were exported to Bomem Grams/ 32 software (version 4.04, 1996) and peak areas were determined by integration. Loss in peak area was determined as a percent of the peak area for the control (day 0) sample.

\section{Infrared Spectroscopy}

Infrared spectra were collected using a Bomem Prota spectrophotometer purged with dry air. BSA solution samples $(40 \mathrm{mg} / \mathrm{mL})$, BSA gels, or precipitated protein samples were applied to a $6 \mu$ path length $\mathrm{CaF}_{2}$ cell. For each protein and buffer sample, a 128-scan interferogram was collected in single-beam mode with a resolution of $4 \mathrm{~cm}^{-1}$ at $37^{\circ} \mathrm{C}$. Thermal control of the sample was maintained with a custom-made thermal cell attached to a circulating water bath. Water vapor and buffer spectra were subtracted as previously described. $^{22}$ Raw data were transformed to second derivative spectra using Bomem Grams/ 32 software (version $4.04,1996$ ) to examine the amide I region $\left(1600-1700 \mathrm{~cm}^{-1}\right)$ as described elsewhere. $^{22}$

\section{Far UV CD Spectroscopy}

Samples were prepared at a BSA concentration of $0.1 \mathrm{mg} / \mathrm{mL}$ and far UV CD scans were collected using an AVIV Model 62DS spectrometer. Data were collected in millidegrees from 190 to $260 \mathrm{~nm}$ at $0.5 \mathrm{~nm}$ intervals using a $0.1 \mathrm{~cm}$ path length quartz cuvette at $37^{\circ} \mathrm{C}$. After buffer subtraction, the raw data were transformed to mean residue ellipticity (MRE, deg $\mathrm{cm}^{2} / \mathrm{dmol}$ ). Deconvolution of far UV CD data was performed using CD Pro software.

\section{Second Derivative UV Absorbance Spectroscopy}

Samples were prepared at $0.5 \mathrm{mg} / \mathrm{mL}$ and placed in a quartz cuvette with a $1 \mathrm{~cm}$ path length. Absorbance spectra $(200-350 \mathrm{~nm}, 240 \mathrm{~nm} / \mathrm{min}$ scan rate) were collected using a Beckman DU640 spectrophotometer at $37^{\circ} \mathrm{C}$. Sample temperature was controlled by using a thermal jacket attached to a circulating water bath, and the temperature of the sample was verified using a thermometer with a Type T thermocouple (Omega Engineering Inc., Stamford, CT). The appropriate buffer spectrum was subtracted from each protein absorbance spectrum. For chemical denaturation studies, BSA was incubated with $5.5 \mathrm{M}$ guanidine hydrochloride ( $\mathrm{GdnHCl}$ ) at $\mathrm{pH} 7$ for $24 \mathrm{~h}$ at room temperature prior to analysis. The concentration of $\mathrm{GdnHCl}$ was determined by refractometry. Data were then exported and transformed to second derivative spectra using Bomem Grams/ 32 software (version 4.04, 1996) using a method previously described. ${ }^{23}$

\section{SDS-PAGE}

BSA samples were subjected to SDS-PAGE analysis using precast gradient gels $(4 \%-20 \%$ Tris-HCl/glycine, Bio-Rad Laboratories, Inc., Hercules, CA) or hand poured 7.5\% gels. Samples were diluted 1:1 in Laemmli sample buffer 
(62.5 mM Tris-HCl, $\mathrm{pH}$ 6.8, 25\% glycerol, $2 \%$ SDS, $0.01 \%$ Bromophenol blue), with or without $750 \mathrm{mM} \beta$-mercaptoethanol, and boiled for $5 \mathrm{~min}$ (with $\beta$-mercaptoethanol) or $1 \mathrm{~min}$ (without $\beta$ mercaptoethanol) prior to loading. Gels were electrophoresed for $1 \mathrm{~h} 10 \mathrm{~min}$ at $180 \mathrm{v}$ and then stained with Coomassie blue to visualize the protein bands.

\section{PLGA Millicylinder Preparation, Incubation, and BSA Extraction}

BSA was encapsulated at $10 \%(\mathrm{w} / \mathrm{w})$ in PLGA millicylinders (50:50, i.v. $0.61 \mathrm{dl} / \mathrm{g}$, Birmingham Polymers, Inc., Birmingham, AL) by a solvent extrusion method. ${ }^{13}$ Briefly, a uniform suspension of sieved BSA powder $(<90 \mu \mathrm{m})$ in $50 \%(\mathrm{w} / \mathrm{w})$ polymer/acetone solution was loaded into a $5 \mathrm{~mL}$ syringe and extruded into silicone tubing $(0.8 \mathrm{~mm}$ I. D.). The extruded suspension was dried at room temperature for $24 \mathrm{~h}$ followed by further drying in a vacuum oven at $45^{\circ} \mathrm{C}$ for another $24 \mathrm{~h}$. The silicon tubing was then cut and millicylinders were retrieved. In vitro release studies were carried out at $37^{\circ} \mathrm{C}$ under mild agitation conditions. Millicylinders $(10 \times 0.8 \mathrm{~mm}, 5-7 \mathrm{mg}$ total weight) were placed in $1.5 \mathrm{~mL}$ eppendorf tubes and incubated with $1 \mathrm{~mL}$ PBST $(7.7 \mathrm{mM}$ $\mathrm{Na}_{2} \mathrm{HPO}$, $2.3 \mathrm{mM} \mathrm{NaH} \mathrm{NO}_{2}, 137 \mathrm{mM} \mathrm{NaCl}$, $3 \mathrm{mM} \mathrm{KCl}, \mathrm{pH} 7.4$ with $0.02 \%$ Tween-80) for 2 weeks. Release medium was then removed and the millicylinder was dissolved in acetone and centrifuged. It has been shown previously that this acetone extraction method does not significantly affect the structure nor induce aggregation of BSA. ${ }^{13}$ The precipitated protein pellets were washed twice with acetone and air-dried, after which $1 \mathrm{~mL}$ PBST was then added. The resulting suspension was incubated at $37^{\circ} \mathrm{C}$ under mild agitation conditions for $1 \mathrm{~h}$ to remove any soluble protein. The remaining precipitate was analyzed by infrared spectroscopy.

\section{RESULTS AND DISCUSSION}

\section{Characterization of BSA Degradation during Incubation at $37^{\circ} \mathrm{C}$}

Degradation of BSA was examined under solution conditions that simulate the environment within PLGA delivery systems during various stages of release. Protein release from PLGA systems occurs in two phases. ${ }^{5,24}$ Initial exposure to the aqueous release media leads to the dissolution and then diffusion of protein molecules on or near the surface of the device, which often results in a burst effect in the release profile. ${ }^{13}$ The second phase occurs as the polymer breaks down by means of hydrolytic scission of ester linkages and begins to erode. During PLGA erosion, the dehydrated protein rehydrates within the PLGA matrix. Thus, local protein concentration within the system may be quite high during the initial stages of rehydration, but is expected to become more dilute as the system continues to take up more water as the polymer degrades, pores are enlarged, and protein is released. ${ }^{5}$ To simulate a range of protein concentrations anticipated in PLGA delivery systems during release, BSA concentrations of 100,40 , and $10 \mathrm{mg} / \mathrm{mL}$ were used in the current study. As a consequence of PLGA breakdown to lactic and glycolic acids during degradation and erosion, the internal PLGA environment can become acidic very rapidly. ${ }^{18-21}$ Therefore, neutral ( $\left.\mathrm{pH} 7\right)$, mildly acidic ( $\mathrm{pH} 5)$, and acidic $(\mathrm{pH} 2)$ conditions were used to represent various stages of acidification. The effects of low-ionic strength $(10 \mathrm{mM}$ potassium phosphate) and high-ionic strength (10 mM potassium phosphate and $150 \mathrm{mM} \mathrm{NaCl}$ ) buffers were also investigated.

BSA degradation under the above solution conditions was assessed initially by determining the level of native monomer after 28 days of incubation at $37^{\circ} \mathrm{C}$ (Tab. 1). Under the conditions examined, BSA was most stable at $\mathrm{pH} 7$ regardless of ionic strength and protein concentration since no significant loss in protein monomer was detected. At $\mathrm{pH} 5$, approximately 5\%-10\% of BSA monomer was lost after 28 days of incubation. The protein concentration had little effect on the degradation of BSA at $\mathrm{pH} 5$. The ionic strength at $\mathrm{pH} 5$, however, had a slight effect on degradation as a greater amount of monomer was lost with the low-ionic strength samples (8.3-10.2\%) when compared to the high-ionic strength samples $(5.7-7.2 \%)$. BSA was the least stable under all $\mathrm{pH} 2$ conditions and no monomer was detectable by the end of the incubation study.

To gain further insight into the kinetics and pathways of BSA instability, the degradation samples incubated at $\mathrm{pH} 2$ were analyzed by SE-HPLC as a function of time during incubation at $37^{\circ} \mathrm{C}$. Loss of monomer proceeded rapidly under both low- (Fig. 1A) and high- (Fig. 1B) ionic strength buffer conditions. The rate of degradation was much more rapid in $100 \mathrm{mg} / \mathrm{mL}$ than in 
Table 1. BSA Monomer Levels (\%) During $37^{\circ} \mathrm{C}$ Incubation $^{a}$

\begin{tabular}{|c|c|c|c|c|}
\hline \multirow[b]{2}{*}{ Sample } & \multicolumn{2}{|c|}{ Low-Ionic Strength } & \multicolumn{2}{|c|}{ High-Ionic Strength } \\
\hline & Day 0 & Day 28 & Day 0 & Day 28 \\
\hline \multicolumn{5}{|l|}{$\mathrm{pH} 2$} \\
\hline $10 \mathrm{mg} / \mathrm{mL}$ & $81.2 \pm 0.3$ & $0.0 \pm 0.0$ & $76.6 \pm 0.4$ & $0.0 \pm 0.0$ \\
\hline $40 \mathrm{mg} / \mathrm{mL}$ & $82.3 \pm 0.1$ & $0.0 \pm 0.0$ & $77.4 \pm 0.4$ & $0.0 \pm 0.0^{b}$ \\
\hline $100 \mathrm{mg} / \mathrm{mL}$ & $80.2 \pm 2.1$ & $0.0 \pm 0.0^{b}$ & $76.0 \pm 1.1$ & $0.0 \pm 0.0^{b}$ \\
\hline \multicolumn{5}{|l|}{ pH 5} \\
\hline $10 \mathrm{mg} / \mathrm{mL}$ & $83.9 \pm 0.3$ & $75.6 \pm 1.0$ & $82.6 \pm 0.1$ & $75.4 \pm 0.8$ \\
\hline $40 \mathrm{mg} / \mathrm{mL}$ & $83.0 \pm 0.4$ & $74.3 \pm 2.0$ & $82.6 \pm 0.1$ & $76.9 \pm 1.3$ \\
\hline $100 \mathrm{mg} / \mathrm{mL}$ & $82.0 \pm 0.4$ & $71.8 \pm 1.2$ & $80.0 \pm 1.2$ & $73.7 \pm 0.3$ \\
\hline \multicolumn{5}{|l|}{ pH 7} \\
\hline $10 \mathrm{mg} / \mathrm{mL}$ & $84.0 \pm 0.3$ & $84.6 \pm 0.9$ & $83.8 \pm 0.2$ & $83.6 \pm 0.4$ \\
\hline $40 \mathrm{mg} / \mathrm{mL}$ & $84.0 \pm 0.2$ & $84.8 \pm 0.6$ & $83.1 \pm 0.3$ & $83.2 \pm 0.5$ \\
\hline $100 \mathrm{mg} / \mathrm{mL}$ & $84.1 \pm 0.2$ & $83.5 \pm 0.6$ & $83.1 \pm 0.8$ & $82.7 \pm 0.2$ \\
\hline
\end{tabular}

$10 \mathrm{mg} / \mathrm{mL}$ or $40 \mathrm{mg} / \mathrm{mL}$ protein samples. For example, samples prepared at $100 \mathrm{mg} / \mathrm{mL}$ lost nearly $50 \%$ of monomeric BSA after only 1 day of incubation whereas samples prepared at $10 \mathrm{mg} /$ $\mathrm{mL}$ required about 5 days to degrade to the same extent. The ionic strength of the solution had a less dramatic effect on BSA stability where, in general, the rate of degradation was slightly higher in samples that contained $150 \mathrm{mM} \mathrm{NaCl}$.

Inspection of the size-exclusion chromatograms revealed that the early loss of monomeric BSA was concomitant with the formation of large, soluble aggregates (Fig. 2A). Such aggregates were present in all $\mathrm{pH} 2$ samples at some stage of the

A

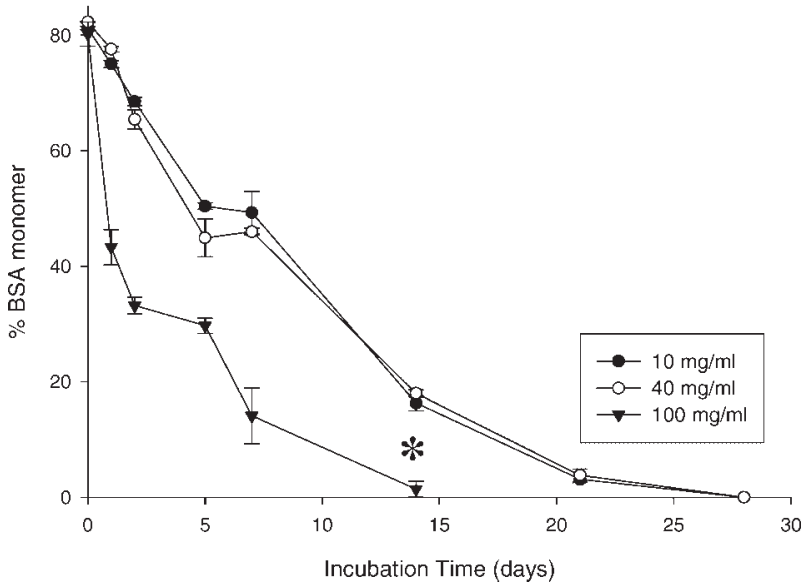

incubation study regardless of the BSA concentration or ionic strength (data not shown). The aggregates eluted in the void volume and suggest a molecular weight greater than $500 \mathrm{kDa}$ based on the resolution of the column and calibration with molecular weight standards (data not shown). The aggregate peak area steadily increased in the first week of incubation at $37^{\circ} \mathrm{C}$. After this initial phase, however, the aggregate peak receded without a proportional recovery of BSA monomer. In some cases $(100 \mathrm{mg} / \mathrm{mL}$ at both low- and high-ionic strength and $40 \mathrm{mg} / \mathrm{mL}$ high-ionic strength) the formation of a protein gel, which could not be dissolved by dilution or isolated by centrifugation,

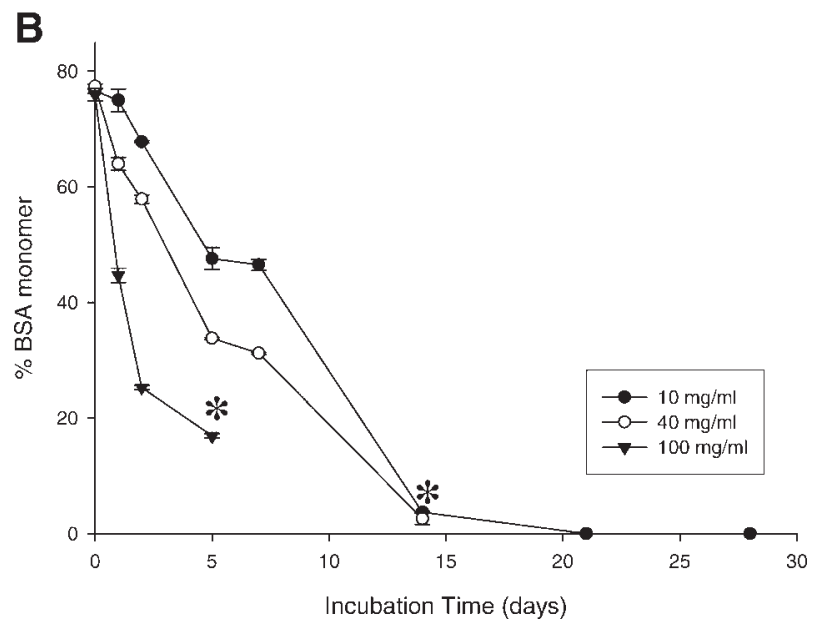

Figure 1. Loss of BSA monomer during incubation at $37^{\circ} \mathrm{C}$ and at $\mathrm{pH} 2$ under low- (A) and high- $(\mathrm{B})$ ionic strength conditions. The * indicates the formation of a protein gel at the subsequent time point, which could not be analyzed by SE-HPLC. Data is shown as mean $\pm \mathrm{SE}(n=3)$, and the error bars may be smaller than the data point in some cases. 


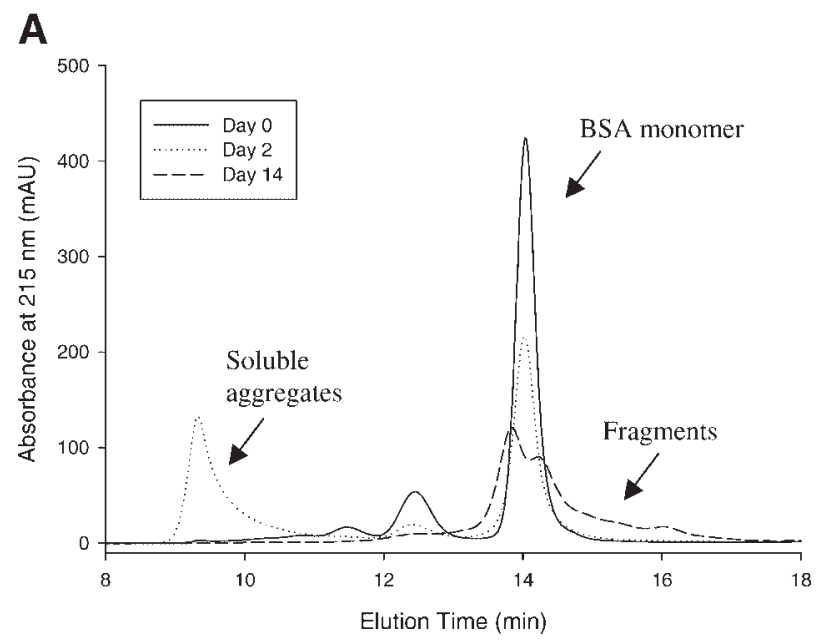

B Day
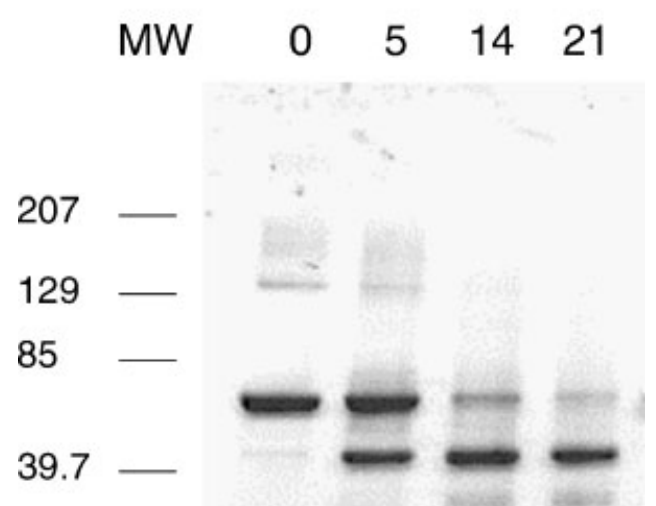

32.1

17.5

7.1

Figure 2. (A) Representative SE-HPLC chromatograms showing the degradation of $\mathrm{BSA}$ at $\mathrm{pH} 2$ during incubation at $37^{\circ} \mathrm{C}$. BSA monomer, soluble aggregates, and peptide fragments are indicted. The protein sample was prepared in high-ionic strength buffer at a protein concentration of $40 \mathrm{mg} / \mathrm{mL}$. (B) SDS-PAGE $(4 \%-20 \%$ gradient gel) analysis reveals peptide bond hydrolysis of BSA during incubation at $37^{\circ} \mathrm{C}$. The sample was prepared at $10 \mathrm{mg} / \mathrm{mL}$ in $\mathrm{pH} 2$ low-ionic strength buffer. Approximate molecular weights are indicated on the left and each lane represents $5 \mu \mathrm{g}$ of total protein. Protein bands were visualized by Coomassie blue staining.

prevented SE-HPLC analysis at further time points. It was also observed that the properties of the gels changed after extended incubation at $37^{\circ} \mathrm{C}$. Gelled samples stored for 3 months at $37^{\circ} \mathrm{C}$ formed a white insoluble protein precipitate that settled at the bottom of the tubes (data not shown).

In addition to aggregation and gel formation, BSA fragmented during incubation at $\mathrm{pH} 2$ and $37^{\circ} \mathrm{C}$ in aqueous solution. Fragmented protein species, most likely due to hydrolysis of acid-labile Asp-Pro peptide bonds, ${ }^{25}$ were seen in the sizeexclusion chromatograms as a shoulder on the monomer peak and as unresolved species eluting afterwards (Fig. 2A). Such signs of chemical degradation were observed to varying degrees in all samples incubated at $\mathrm{pH} 2$ (data not shown). To further evaluate the fragmentation of BSA the samples were analyzed by SDS-PAGE, which showed the progressive loss of monomeric BSA and formation of several peptide species with molecular weights ranging from approximately 7 to $40 \mathrm{kDa}$ (Fig. 2B). The number and intensity of the fragments increased with the incubation time, indicating that BSA continued to hydrolyze throughout the incubation period. A small amount of intact BSA monomer was still detectable at the end of the incubation period, however, which suggests that the hydrolysis was not complete.

BSA degradation during incubation at $\mathrm{pH} 5$ occurred mainly through the formation of insoluble precipitates that were observed in all samples for which there was a measurable monomer loss (Tab. 1). The secondary structure of the isolated aggregates, collected by centrifugation, was examined using infrared spectroscopy. Native BSA is a globular protein with a high content of $\alpha$-helix structure $(55-65 \%),{ }^{26,27}$ represented by a large band at $1657 \mathrm{~cm}^{-1}$ in the second derivative infrared spectrum of the conformationally sensitive amide I region. ${ }^{22}$ As expected, BSA in solution under mildly acidic conditions (pH 5) also demonstrated this characteristic $\alpha$-helix band as well as turn $\left(1680 \mathrm{~cm}^{-1}\right), \beta$-sheet (1684 and $\left.1628 \mathrm{~cm}^{-1}\right)$, and unordered $\left(1638 \mathrm{~cm}^{-1}\right)$ components (Fig. 3A). The infrared spectrum of the insoluble protein had only a slight loss in the intensity at $1657 \mathrm{~cm}^{-1}$ ( $\alpha$-helix band) when compared to BSA in solution at $\mathrm{pH}$ 5. Additionally, the appearance of minor bands at 1695 and $1618 \mathrm{~cm}^{-1}$ due to the formation of intermolecular $\beta$-sheet bands were noted, which are indicative of nonnative aggregation. ${ }^{22,28}$ This data suggests that the BSA aggregates produced during incubation at $\mathrm{pH} 5$ are relatively nativelike since only slight changes in the secondary structure were detectable. To determine if aggregates formed at $\mathrm{pH} 5$ contained covalent crosslinks, the insoluble material was collected by 


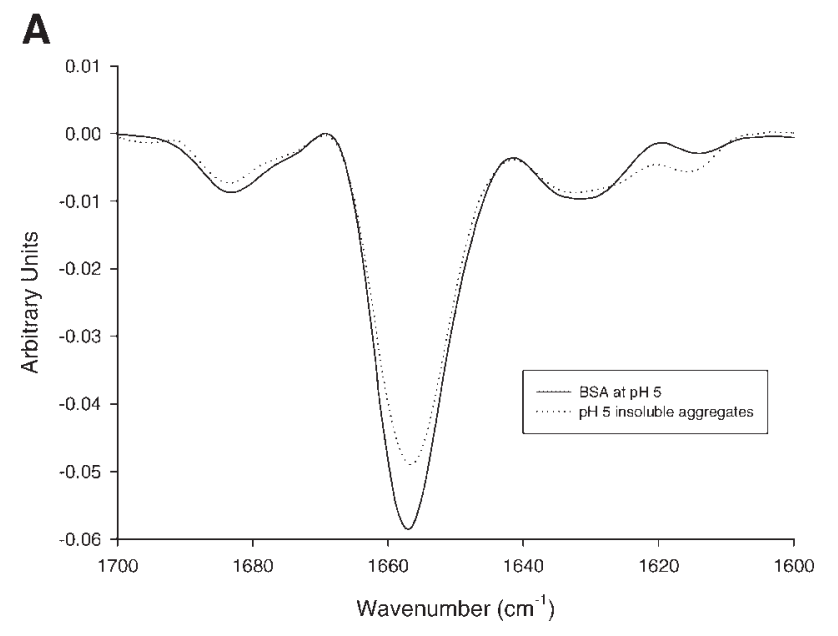

B

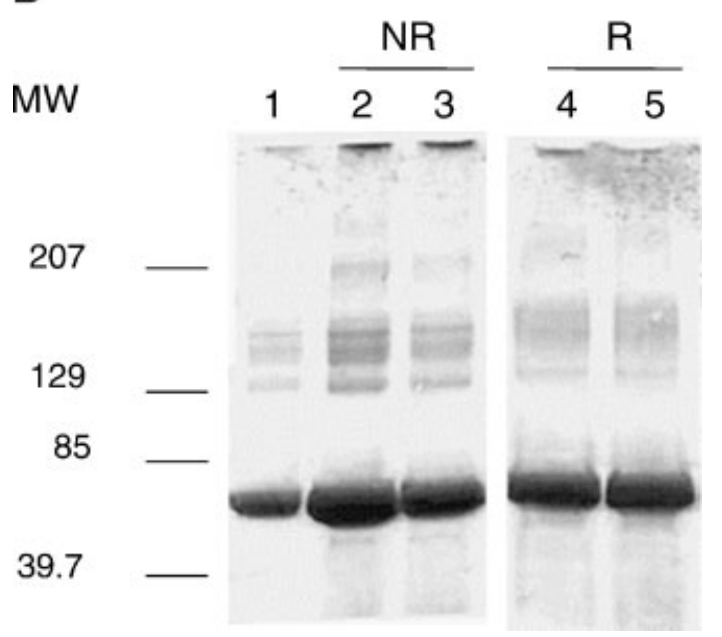

Figure 3. (A) FTIR analysis of insoluble BSA aggregates formed during $37^{\circ} \mathrm{C}$ incubation at $\mathrm{pH} 5$ and highionic strength buffer at $100 \mathrm{mg} / \mathrm{mL}$ protein concentration. BSA prepared at $\mathrm{pH} 5$ low-ionic strength buffer at $40 \mathrm{mg} / \mathrm{mL}$ is also shown for comparison. Each spectrum is an average of three independent samples. (B) SDSPAGE $(7.5 \%$ gel) analysis of insoluble BSA aggregates formed after 28 days of incubation at $37^{\circ} \mathrm{C}$ and $\mathrm{pH} 5$ at $100 \mathrm{mg} / \mathrm{mL}$ under both low- and high-ionic strength conditions. Approximate molecular weights are indicated on the left and $5 \mu \mathrm{g}$ of control BSA is shown (lane 1 ). Lanes 2 and 4 are approximately $10 \mu \mathrm{g}$ of BSA incubated in low-ionic strength buffer, and lanes 3 and 5 are approximately $10 \mu \mathrm{g}$ of BSA incubated in high-ionic strength buffer under both nonreducing (NR) and reducing $(\mathrm{R})$ conditions. Protein bands were visualized by Coomassie blue staining.

centrifugation and analyzed using SDS-PAGE (Fig. 3B). Most of the insoluble aggregates dissociated into monomeric BSA and high-molecular weight covalent species that were also present in the starting material, though a small amount of material remained in the well. Upon the addition of a reducing agent, the majority of these species dissolved and migrated through the gel. Taken together, these data indicate that the aggregates found at $\mathrm{pH} 5$ are mainly noncovalent in nature with a small amount of disulfide cross-linked species.

\section{Comparison of PLGA- and pH-induced BSA Degradation}

Previous studies with BSA encapsulated within PLGA delivery devices, including microspheres as well as millicylinders, have demonstrated incomplete release profiles. ${ }^{13}$ Specifically, BSA encapsulated within PLGA initially undergoes a burst release from the delivery system after which a minimal amount of protein is released at later time points. ${ }^{13}$ Examination of the protein that remained entrapped within the PLGA revealed noncovalent aggregation as well as peptide bond fragmentation, indicative of exposure to a highly acidic environment. Thus, the incomplete release of BSA and other proteins from PLGA devices has been attributed in part to the acidification of the internal microclimate, which has been documented through various lines of research. The use of $\mathrm{pH}$ sensitive probes, ${ }^{19,21}$ electron paramagnetic resonance spectroscopy, ${ }^{18}$ and potentiometric techniques ${ }^{29}$ have demonstrated that the microenvironment within the PLGA becomes acidified during in vitro release with $\mathrm{pH}$ values as low as 2 reported. In experiments in which BSA was lyophilized from various solution $\mathrm{pHs}$ and then exposed to high relative humidity, it was found that only protein lyophilized from $\mathrm{pH} 2$ leads to degradation products similar to that observed with PLGA systems. ${ }^{13}$ Furthermore, the incorporation of a poorly water-soluble base, $\mathrm{Mg}(\mathrm{OH})_{2}$, prevents degradation and improves release of BSA in PLGA systems. ${ }^{13}$ These observations support the hypothesis that the acidification of the internal microclimate of the PLGA system is a dominant stress for proteins during release, presumably due to acid denaturation of the protein.

To further examine this hypothesis, the products of BSA degradation within PLGA millicylinders were compared to those observed upon incubation under acidic conditions ( $\mathrm{pH}$ 2). PLGA millicylinders were prepared with $10 \%$ BSA as described in the Materials and Methods. The 
millicylinders were then exposed to PBST release medium for 2 weeks at $37^{\circ} \mathrm{C}$, after which no further protein was released from the device. The trapped BSA, which was the insoluble protein residue and determined to be $53 \%$ of total encapsulated BSA, was extracted and analyzed by infrared spectroscopy. The infrared spectrum for the extracted aggregates from the PLGA millicylinders revealed an immense loss of native $\alpha$-helix content $\left(1657 \mathrm{~cm}^{-1}\right)$ and a high level of intermolecular $\beta$ sheet (1618 and $1695 \mathrm{~cm}^{-1}$ ) compared to BSA in solution (Fig. 4). The BSA aggregates extracted from the PLGA millicylinders have highly disrupted secondary structure, presumably due to nonnative contacts and extensive aggregation. The extracted protein from the PLGA millicylinders was also compared to the BSA aggregates observed during incubation of the protein at $37^{\circ} \mathrm{C}$ and $\mathrm{pH} 2$. It is anticipated that if acidification is the dominant pathway of BSA instability within the PLGA millicylinders then incubation under acidic conditions ( $\mathrm{pH} 2$ ) should produce similar degradation products, including protein aggregates. In fact, the infrared spectrum of the BSA gels detected at $\mathrm{pH} 2$ revealed nearly identical spectral properties, namely extensive loss of $\alpha$-helix and concomitant formation of intermolecular $\beta$-sheet structures, as to that of the protein extracted from the PLGA (Fig. 4). It is interesting to consider the BSA aggregates detected during incubation

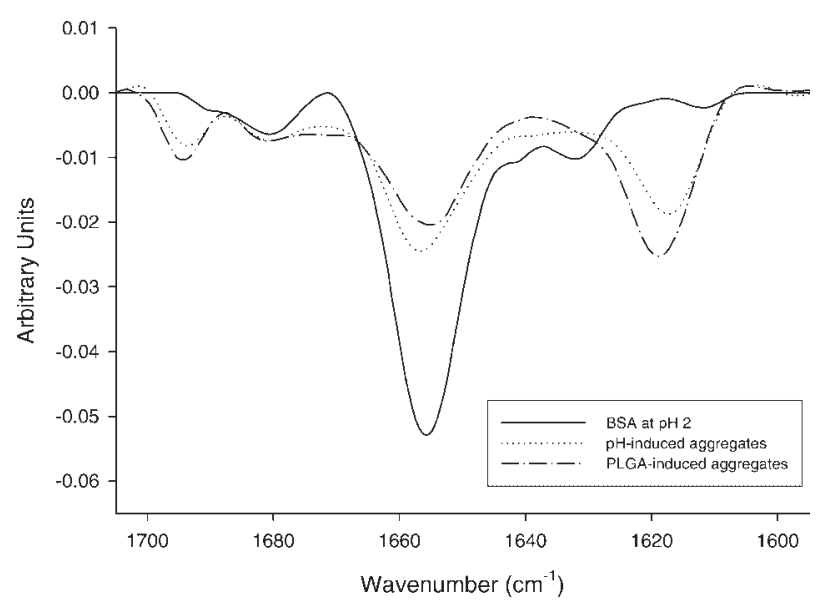

Figure 4. FTIR analysis of BSA aggregates from $\mathrm{pH}-$ and PLGA-induced stresses. Aggregates extracted from PLGA millicylinder after 2 weeks of incubation at $37^{\circ} \mathrm{C}$ in release media compared to BSA gel produced from incubation at $\mathrm{pH} 2$ for 7 days at $37^{\circ} \mathrm{C}(100 \mathrm{mg} / \mathrm{mL}$ and high-ionic strength buffer). BSA prepared at $\mathrm{pH} 2$, $40 \mathrm{mg} / \mathrm{mL}$, and high-ionic strength buffer, is also shown for comparison. Each spectrum represents an average of three independent samples. under only mildly acidic conditions ( $\mathrm{pH}$ 5) showed only minimal structural changes in comparison (Fig. 3A). Taken together, these data suggest that mildly acidic conditions within the PLGA device would not be sufficient to produce the aggregates observed in the extracted material. Rather, the microclimate must acidify to a much lower $\mathrm{pH}$ to produce the aggregates found trapped within the PLGA matrix in this study. It is important to note that BSA gels were not observed in the sample extracted from PLGA millicylinders. BSA gels incubated for an extended period of time (3 months) at $37^{\circ} \mathrm{C}$, however, lost gel-like properties and formed a white precipitate that settled on the bottom of the tube. Infrared spectroscopic analysis of the precipitated BSA revealed similar spectral characteristics to that of the gelled BSA (data not shown).

As discussed above, similarities are expected between BSA exposed to acidic $(\mathrm{pH}$ 2) solution conditions and that extracted from PLGA millicylinders if acidification of the microclimate $\mathrm{pH}$ during release is a dominant protein stress. Previous studies with BSA encapsulated within PLGA-delivery devices revealed extensive hydrolysis of the protein. ${ }^{13}$ In this study, we observed unresolved species eluting after the BSA monomer by SE-HPLC during incubation at $\mathrm{pH} 2$ that suggested fragmentation of the protein (Fig. 2A). Additionally, we confirmed that BSA had undergone hydrolysis by SDS-PAGE, in which a variety of protein fragments ranging from 7 to $40 \mathrm{kDa}$ were seen (Fig. 2B). In contrast, BSA samples that were incubated under only mildly acidic conditions ( $\mathrm{pH} 5)$ did not display detectable fragmentation in SDS-PAGE gels (Fig. 3B). These results follow the trend observed with the extent of secondary structure perturbation in the insoluble BSA aggregates at $\mathrm{pH} 2$ (Fig. 4) and 5 (Fig. 3A), indicating that exposure to acidic conditions $(\mathrm{pH} 2)$ are responsible for the degradation found within PLGA millicylinders.

To better understand the structural basis of BSA instability under acidic conditions, the kinetics of secondary structural transitions accompanying BSA aggregation at $\mathrm{pH} 2$ were also examined by infrared spectroscopy. BSA prepared at $\mathrm{pH} 2$ demonstrated a high content of $\alpha$-helix as well as turn, $\beta$-sheet and unordered structures ${ }^{22}$ (Fig. 5). BSA quickly loses native secondary structure (primarily $\alpha$-helix content) when incubated at $37^{\circ} \mathrm{C}$ and $\mathrm{pH} 2$, and forms nonnative aggregates signified by intermolecular $\beta$-sheet in the infrared spectra. ${ }^{28}$ After only $2 \mathrm{~h}$ of incubation 


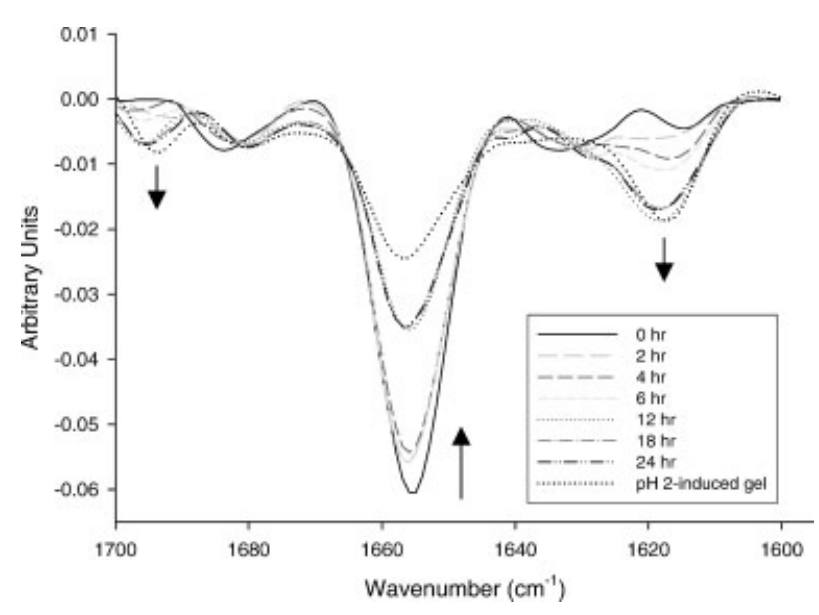

Figure 5. Changes in the secondary structure of BSA monitored by FTIR. The sample was prepared at $100 \mathrm{mg} /$ $\mathrm{mL}$ in $\mathrm{pH} 2$ high-ionic strength buffer and spectra were collected at various time-points during incubation at $37^{\circ} \mathrm{C}$ until and gel formation (day 7). Arrows indicate the loss of $\alpha$-helix $\left(1657 \mathrm{~cm}^{-1}\right)$ and formation of intermolecular $\beta$-sheet (1618 and $1695 \mathrm{~cm}^{-1}$ ), respectively. Each spectrum represents an average of three independent samples.

at $37^{\circ} \mathrm{C}$, the intensity of the $\alpha$-helix band was noticeably reduced and continued to decrease in a time-dependent manner. The formation of new bands at 1695 and $1618 \mathrm{~cm}^{-1}$, indicative of intermolecular $\beta$-sheet structures, was also observed. This trend continued until $12 \mathrm{~h}$ of incubation, after which there was little change until the protein gel formed (day 7). The protein gel demonstrated an even greater loss in native $\alpha$ helical content and a larger amount of intermolecular $\beta$-sheet compared to the $24 \mathrm{~h}$ spectrum. All gelled BSA samples, $100 \mathrm{mg} / \mathrm{mL}$ (low- and highionic strength buffer) and $40 \mathrm{mg} / \mathrm{mL}$ (high-ionic strength buffer), had nearly identical infrared spectra (data not shown).

\section{Effect of Solution Conditions on BSA Structure}

To better understand how solution conditions affect degradation pathways of BSA, the structure of the protein was examined under the solution conditions employed in this study. The secondary structure of BSA was evaluated using infrared spectroscopy under both low- (Fig. 6A) and high(Fig. 6B) ionic strength conditions. At $\mathrm{pH}$ 7, BSA is composed of a high amount of $\alpha$-helix content by a strong band at $1657 \mathrm{~cm}^{-1}$ and other bands attributed to $\beta$-sheet structures (1691, 1640, and $\left.1631 \mathrm{~cm}^{-1}\right)$, turn $\left(1681 \mathrm{~cm}^{-1}\right)$, and random coil $\left(1650 \mathrm{~cm}^{-1}\right){ }^{22}$ The ionic strength of the buffer did
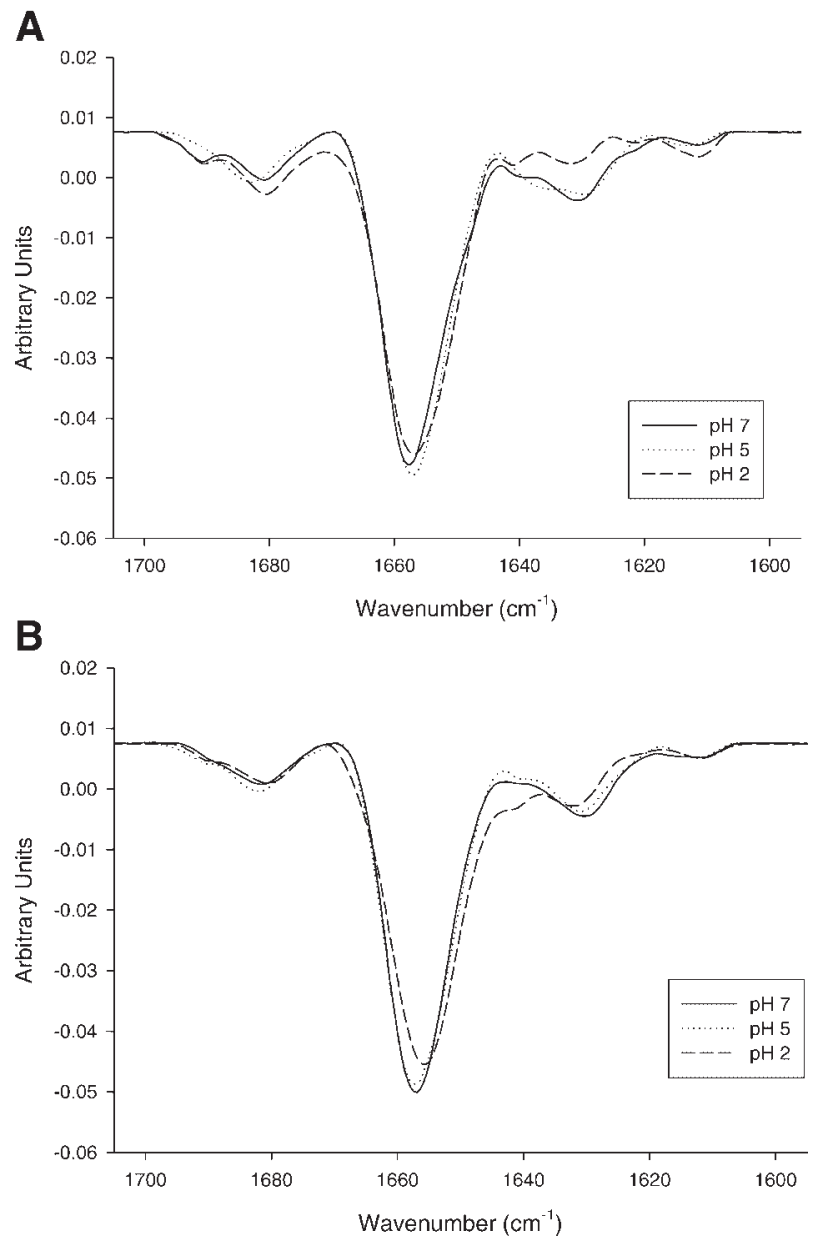

Figure 6. FTIR of BSA (40 mg/mL) prepared under various $\mathrm{pHs}$ in low- (A) and high- (B) ionic strength buffers. Data were collected at $37^{\circ} \mathrm{C}$ and each spectrum represents an average of at least three independent samples.

not affect the secondary structure of BSA at either $\mathrm{pH} 5$ or 7 , nor were there substantial differences in the spectra for samples between these two pHs. Visual inspection of the Fourier-transform infrared spectroscopy (FTIR) spectra of BSA at $\mathrm{pH} 2$, however, revealed subtle changes. In addition to minor structural rearrangements of $\beta$-sheet components (1638 to $1618 \mathrm{~cm}^{-1}$ ), the position of the $\alpha$ helix band appeared to shift slightly from 1657 to $1655 \mathrm{~cm}^{-1}$, and a small decrease in intensity of this band was also noted. These structural changes were most pronounced in the low-ionic strength samples, in which the bandwidth of the $\alpha$-helix band also appeared to increase. Analysis of the fourth derivative of the infrared spectra resolved a new band at $1649 \mathrm{~cm}^{-1}$, assigned to unordered structure, ${ }^{22}$ which was detectable only in the low-ionic strength samples at $\mathrm{pH} 2$ (data 
not shown). This suggests that BSA underwent unfolding at $\mathrm{pH} 2$ and low-ionic strength as native $\alpha$-helix was converted to unordered structures. The lack of this new peak in the fourth derivative of the high-ionic strength samples indicates that BSA retains more native secondary structure under these solution conditions.

To confirm the FTIR results, far UV CD spectroscopy was also used to examine the secondary structure of BSA as a function of the solution conditions. The far UV CD spectra of BSA at $\mathrm{pH} 7$ in both high- (Fig. 7B) and low-ionic strength buffers (Fig. 7A) had two strong negative bands at 208 and $222 \mathrm{~nm}$ as well as a strong positive band at $195 \mathrm{~nm}$. These properties are attributed to a high content of $\alpha$-helix structure in proteins. ${ }^{30}$ At $\mathrm{pH} 5$, a small decrease in the intensity of the 208 and $222 \mathrm{~nm}$ bands was seen at both ionic strengths. The spectrum for BSA under $\mathrm{pH} 2$ and low-ionic

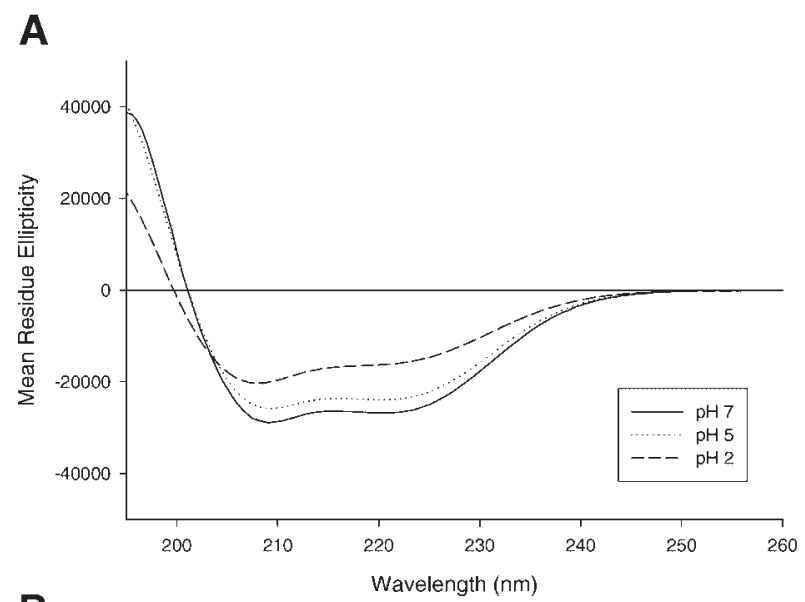

B

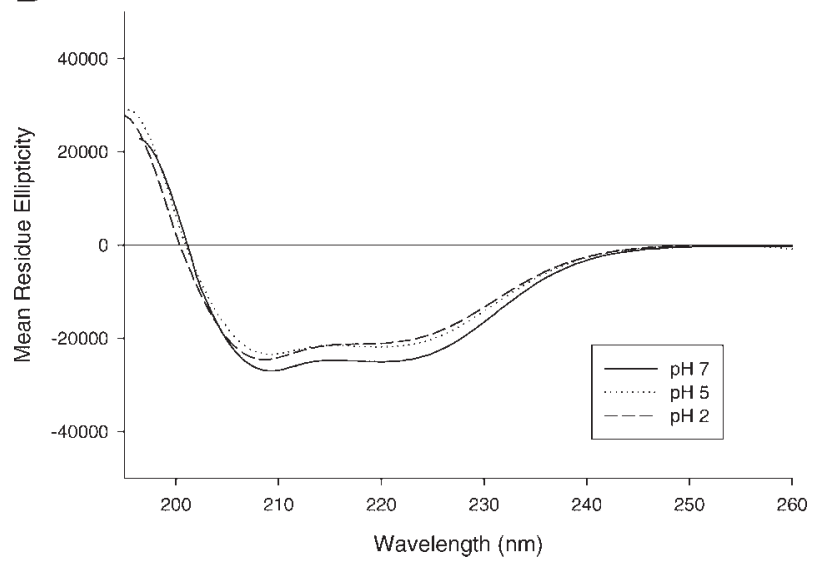

Figure 7. Far UV CD scans of BSA $(0.1 \mathrm{mg} / \mathrm{mL})$ prepared under various pHs in low- (A) and high- (B) ionic strength buffers. Scans were collected at $37^{\circ} \mathrm{C}$ and each scan represents an average of three independent samples. strength conditions had a large decrease in intensity of all $\alpha$-helix bands and a blue shift in the $208 \mathrm{~nm}$ band. This points to a substantial loss in native structure at $\mathrm{pH} 2$ and low-ionic strength. In contrast, the spectrum of BSA at $\mathrm{pH} 2$ and highionic strength was only slightly different than that for the protein at $\mathrm{pH}$ 7. These changes were quantitated by deconvoluting the far UV CD data using CD Pro software (Tab. 2). In agreement with the visual inspection of the spectra, BSA contained a high amount of $\alpha$-helix structure at both $\mathrm{pH} 5$ and 7 with no significant effect induced by the ionic strength of the solution. BSA prepared at $\mathrm{pH} 2$ and low ionic strength lost over $15 \%$ of native $\alpha$-helical content, and gained content in all other structure with the greatest increase in turn $(9.0 \%$ to $18.8 \%)$. $\mathrm{BSA}$ at $\mathrm{pH} 2$ and high-ionic strength, however, did not differ in secondary structure content from $\mathrm{pH} 7$ (Tab. 2). Thus, the presence of $150 \mathrm{mM} \mathrm{NaCl}$ in the protein solution at $\mathrm{pH} 2$ resulted in much less disruption in the secondary structure of the protein compared to low-ionic strength samples.

Changes in the tertiary structure of BSA were examined by second derivative UV absorption spectroscopy, which is sensitive to the polarity, and thus the solvent exposure, of the local environments of aromatic residues. ${ }^{31}$ The spectrum of BSA at $\mathrm{pH} 7$ showed two peaks in the region from 270 to $300 \mathrm{~nm}$ : $285.3 \mathrm{~nm}$ due to both Trp and Tyr residue contributions and $277.8 \mathrm{~nm}$ primarily from Tyr residues (Fig. 8). The spectra of the protein at $\mathrm{pH} 5$ and 7 were nearly superimposable, signifying that there were minimal differences in the tertiary structure of BSA under these solution conditions at least in terms of local Tyr and Trp environment. In contrast, the spectrum of BSA under $\mathrm{pH} 2$ solution conditions demonstrated a large blue shift in both of the second derivative peaks and the appearance of a third peak $(291 \mathrm{~nm})$ that was previously undetectable and largely attributed to Trp. This change in the peak positions indicates that the aromatic residues were much more solvent exposed at $\mathrm{pH} 2$ when compared to $\mathrm{pH} 5$ or $7 .{ }^{31} \mathrm{In}$ fact, the second derivative peak positions of BSA at $\mathrm{pH} 2$ closely approach the positions of the protein denatured by 5.5 M GdnHCl (Tab. 3). There was a noticeable difference in peak positions between the $\mathrm{pH} 2$ samples prepared at low- and high-ionic strength; $\mathrm{BSA}$ at $\mathrm{pH} 2$ and high-ionic strength showed somewhat less blue-shifting in the second derivative absorbance data. Following a similar trend seen in the spectroscopic analysis of the secondary structure, the addition of $150 \mathrm{mM} \mathrm{NaCl}$ helped to 
Table 2. Deconvolution Results of Far UV Circular Dichroism of BSA Under Various Solution Conditions ${ }^{a}$

\begin{tabular}{lcrrr}
\hline Sample & $\alpha$-Helix & $\beta$-Sheet & \multicolumn{1}{c}{ Turn } & Random \\
\hline pH 7 & & & & \\
$\quad$ Low-ionic strength & $68.5 \pm 4.0$ & $4.5 \pm 0.6$ & $9.0 \pm 1.5$ & $17.9 \pm 2.4$ \\
$\quad$ High-ionic strength & $61.9 \pm 2.3$ & $6.0 \pm 0.7$ & $12.0 \pm 1.2$ & $20.4 \pm 1.3$ \\
pH 5 & & & & \\
Low-ionic strength & $64.7 \pm 2.2$ & $3.3 \pm 0.4$ & $10.4 \pm 1.4$ & $21.6 \pm 1.2$ \\
$\quad$ High-ionic strength & $66.8 \pm 3.5$ & $3.9 \pm 0.5$ & $10.9 \pm 1.8$ & $18.4 \pm 1.6$ \\
PH 2 & & & & \\
$\quad$ Low-ionic strength & $51.0 \pm 1.1$ & $7.4 \pm 0.9$ & $18.8 \pm 0.4$ & $23.6 \pm 0.5$ \\
$\quad$ High-ionic strength & $62.4 \pm 4.3$ & $4.0 \pm 0.7$ & $13.3 \pm 2.2$ & $20.6 \pm 2.4$ \\
\hline
\end{tabular}

\footnotetext{
${ }^{a}$ Quantitation of secondary structure elements (\%) by CD Pro software. Values represent mean $\pm \mathrm{SE}(n=9)$.
}

maintain the native conformation of BSA when exposed to acidic solution conditions, although not nearly to the extent observed in secondary structure analyses.

The structural changes observed with BSA at $\mathrm{pH} 2$ can be explained by acid denaturation of the protein. The structure of BSA is $\mathrm{pH}$ sensitive and the protein undergoes a structural transition at $\mathrm{pH} 2.7$ to form a partially unfolded state. ${ }^{26,27}$ Under acidic conditions ( $\mathrm{pH} 2$ ), all of the ionizable protein groups $\left(\mathrm{pK}_{\mathrm{a}}>3\right)$ are protonated and charge repulsion drives the unfolding of the molecule. ${ }^{32}$ Often, acid denaturation results in severe loss in native tertiary structure though the secondary structure may or may not be disturbed. ${ }^{33,34}$ Consistent with acid denaturation of proteins, BSA samples prepared under acidic solution conditions ( $\mathrm{pH} \mathrm{2}$ ) exhibited a moderate disruption in the secondary structure, characterized by a loss of native $\alpha$-helical content and an

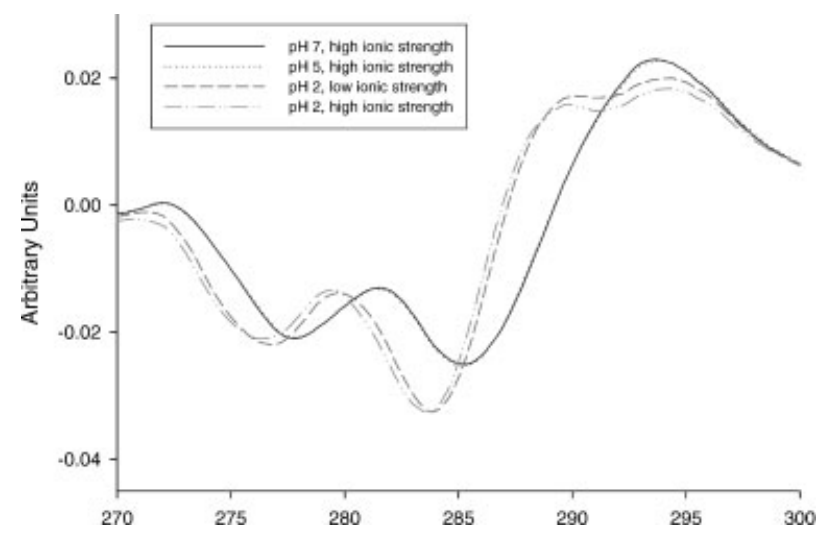

Figure 8. Second derivative UV absorbance spectra of BSA $(0.5 \mathrm{mg} / \mathrm{mL})$ under various solution conditions. Data was collected at $37^{\circ} \mathrm{C}$. Each spectrum represents an average of five independent samples. increase in turn as well as unordered structures in both FTIR (Fig. 6) and far UV CD spectra (Fig. 7). The tertiary structure of BSA at $\mathrm{pH} 2$, however, was greatly compromised. The second derivative $\mathrm{UV}$ absorbance spectrum of BSA at $\mathrm{pH} 2$ more closely resembled BSA unfolded by $5.5 \mathrm{M} \mathrm{GdnHCl}$ rather than native BSA, suggesting a substantial extent of unfolding in the tertiary structure (Tab. 3).

The structural consequences of acid denaturation contribute to the instability of BSA at $\mathrm{pH} 2$ in terms of both physical and chemical degradation pathways. The Lumry-Eyring model describes protein aggregation as a two-step process that is initiated by a conformational change in the protein leading to the formation of an aggregate-prone intermediate. ${ }^{35}$ These species then undergo an assembly process to generate protein aggregates. Acid denaturation of BSA under acidic conditions $(\mathrm{pH} 2)$ leads to partial unfolding of the protein. During the first $24 \mathrm{~h}$ of incubation at $\mathrm{pH} 2$, BSA quickly adopts a partially unfolded conformation characterized by a loss in $\alpha$-helix structure as observed by FTIR analysis (Fig. 5). This aciddenatured state is an aggregate prone intermediate that instigates soluble aggregation and, in some cases, the formation of protein gels. Partial unfolding of the protein also contributes to the chemical degradation observed in this study. Under acidic conditions, the protein backbone is susceptible to peptide bond hydrolysis. Peptide bonds that contain Asp residues have been reported to hydrolyze more than 100 times more rapidly than other peptide bonds, ${ }^{36}$ of which AspPro bonds the most sensitive to hydrolysis. ${ }^{25}$ In the native conformation, a limited number of such bonds are accessible and easily hydrolyzed. Upon unfolding, previously inaccessible regions of the 
Table 3. Second Derivative UV Peak Positions of BSA Under Various Solution Conditions $^{a}$

\begin{tabular}{lccc}
\hline Sample & Peak 1 & Peak 2 & Peak 3 \\
\hline pH 7 & & & \\
$\quad$ Low-ionic strength & $277.79 \pm 0.00$ & $285.33 \pm 0.03$ & $\mathrm{ND}^{b}$ \\
High-ionic strength & $277.77 \pm 0.02$ & $285.31 \pm 0.02$ & $\mathrm{ND}$ \\
pH 5 & & & \\
$\quad$ Low-ionic strength & $277.82 \pm 0.02$ & $285.23 \pm 0.05$ & $\mathrm{ND}$ \\
$\quad$ High-ionic strength & $277.83 \pm 0.07$ & $285.26 \pm 0.04$ & $\mathrm{ND}$ \\
pH 2 & & & \\
Low-ionic strength & $276.32 \pm 0.06$ & $283.65 \pm 0.02$ & $291.13 \pm 0.07$ \\
$\quad$ High-ionic strength & $276.80 \pm 0.01$ & $283.82 \pm 0.03$ & $291.02 \pm 0.06$ \\
5.5 M GdnHCl & $275.61 \pm 0.11$ & $283.14 \pm 0.02$ & $290.97 \pm 0.05$ \\
\hline
\end{tabular}

${ }^{a}$ Spectra were collected at $37^{\circ} \mathrm{C}$. Values represent mean $\pm \mathrm{SE}(n=5)$.

${ }^{b} \mathrm{ND}$ denotes that no peak was detected at that position under the solution conditions described.

protein become solvent exposed and vulnerable to hydrolysis reactions. BSA contains 2 Asp-Pro and 4 Pro-Asp linkages, ${ }^{26}$ hydrolysis of which could generate the fragments detected by SDS-PAGE (Fig. 2B). Peptide bond hydrolysis is detectable throughout the incubation period at $\mathrm{pH} 2$ though soluble aggregation only occurs in the first 2 weeks of the incubation. This suggests that the soluble aggregates that do not form protein gels are eventually hydrolyzed to peptide fragments.

Proteins that are extensively unfolded at $\mathrm{pH} 2$ have been observed to regain some native structure in the presence of salt or by further titration with acid. ${ }^{33}$ We observed that the addition of $150 \mathrm{mM} \mathrm{NaCl}$ significantly reduced the perturbations in the secondary structure of BSA at pH 2 . Structural changes in the secondary structure of BSA at $\mathrm{pH} 2$, including loss of $\alpha$-helix content and an increase in unordered structure, were less severe in the presence of $150 \mathrm{mM} \mathrm{NaCl}$ in both FTIR (Fig. 6) and far UV CD analyses (Fig. 7). A similar though less dramatic effect was also seen with the tertiary structure of the protein as noted by the reduction in the degree of blue shifting in the second derivative absorbance spectra (Fig. 8). Salt-dependent refolding of acid-denatured proteins is primarily attributed to anion binding. ${ }^{33} \mathrm{It}$ is likely that electrostatic interactions between the chloride anions and the protonated sites on the protein molecule provided a "masking" effect of the repulsive positive charges, this allowing the protein to adopt a more native-like conformation. ${ }^{37}$ Charge masking can also affect the colloidal stability of the protein and, therefore, may be responsible for the differences in BSA aggregation and gel formation at $\mathrm{pH} 2$. Positive charges on the surface of the protein at $\mathrm{pH} 2$ contribute to unfavorable protein-protein interactions due to repulsive charges between molecules. Upon the addition of salt, however, the interaction between protein molecules would become more favorable as a result of charge masking. Protein aggregation is an assembly process dependent upon proteinprotein interactions, and it would be therefore expected that aggregation would proceed more rapidly under conditions in which such interactions are more favorable. ${ }^{37}$ We observed that BSA samples prepared at high-ionic strength degraded slightly faster (Fig. 1) and were more likely to form protein gels (Tab. 1) when compared to samples prepared at low-ionic strength, most likely the result of charge masking on colloidal stability.

\section{CONCLUSIONS}

In this study, we have examined how BSA rapidly degrades during incubation under acidic solution conditions in detail. Our work shows that the acid denaturation of BSA at $\mathrm{pH} 2$ leads to substantial loss of native tertiary structure. Such changes in the conformation of the protein result in aggregation and increased peptide bond hydrolysis, providing the basis of instability observed in the current study as well as prior work. ${ }^{13}$ The great similarity between the degradation products observed with BSA encapsulated within PLGA millicylinders and that induced by acidic $(\mathrm{pH} 2)$ solution conditions indicate that acidification within PLGA during release leads to the acid denaturation of BSA and consequent degradation of the protein.

Future development of PLGA delivery systems for controlled release of protein therapeutics must 
take into account the conformational stability of the protein. We have shown that BSA loses native structure and is, therefore, susceptible to degradation under acidic conditions that may exist in the internal PLGA pores during the release phase due to the erosion of the matrix, ${ }^{19,20}$ and may also be representative of acid-labile proteins in general. Stabilization strategies employed to increase native BSA structure within PLGA devices have demonstrated greater success during release than with systems in which the native structure has been left to chance. For example, the use of trehalose during encapsulation of BSA within PLGA microspheres improved both the preservation of native protein structure as well as release of native protein from the device. ${ }^{38}$ The incorporation of poorly-water soluble bases, such as $\mathrm{Mg}(\mathrm{OH})_{2}$, has also been shown to dramatically increase the release of BSA from PLGA systems by controlling the microclimate $\mathrm{pH}^{12,13}$ We anticipate that such stabilization strategies will be important in the future development of successful controlled-release systems for therapeutic proteins.

\section{ACKNOWLEDGMENTS}

We thank Dr. Derrick Katayama and Dr. Lisa Kueltzo for valuable discussion and critical review of this manuscript. This research was funded in part by NIH HL 68345 and an NIH Leadership in Biotechnology Fellowship awarded to T.E.

\section{REFERENCES}

1. Putney SD, Burke PA. 1998. Improving protein therapeutics with sustained-release formulations. Nat Biotechnol 16:153-157.

2. Austin PE, Dunn KA, Eily-Cofield K, Brown CK, Wooden WA, Bradfield JF. 1995. Subcuticular sutures and the rate of inflammation in noncontaminated wounds. Ann Emerg Med 25:328-330.

3. Wise DL, Fellma TD, Sanderson JE, Wentworth RL. 1979. Lactic/glycolic acid polymers. In: Gregoriadis G, editor. Drug carriers in biology and medicine. London: Academic Press, pp 237270.

4. Gilding DK. 1981. Biodegradable polymers. Biocompat Clin Impant Mater 2:209-232.

5. Gombotz WR, Pettit DK. 1995. Biodegradable polymers for protein and peptide drug delivery. Bioconjug Chem 6:332-351.
6. Wise DL, Jackanics TM, Nash HA, Gregory JB. 1973. Polylactic acid as a biodegradable carrier for contraceptive steroids. Contraception 8:227-234.

7. Beck LR, Pope VZ, Cowsar DR, Lewis DH, Tice TR. 1980. Evaluation of a new three-month contraceptive microsphere system in primates. $J$ Contracept Deliv Sys 1:79-82.

8. Hutchinson FG, Furr BJA. 1985. Biodegradable polymers for sustained release of peptides. Biochem Soc Trans 13:502-523.

9. Sanders LM, Kell BA, McRea GI, Whitehead GW. 1986. Prolonged controlled release of nafarelin, a luteinizing hormone-releasing hormone analogue, from biodegradable polymeric implants: Influence of composition and molecular weight of polymer. J Pharm Sci 75:356-360.

10. Johnson OL, Cleland JL, Lee HJ, Charnis M, Duenas E, Jaworowicz W, Shepard D, Shahzamani A, Jones AJ, Putney SD. 1996. A month-long effect from a single injection of microencapsulated human growth hormone. Nat Med 2:795-799.

11. Kim HK, Park TG. 1999. Microencapsulation of human growth hormone within biodegradable polyester microspheres: Protein aggregation stability and incomplete release mechanism. Biotechnol Bioeng 65:659-667.

12. Zhu G, Schwendeman SP. 2000. Stabilization of proteins encapsulated in cylindrical poly(lactide-coglycolide) implants: Mechanisms of stabilization by basic additives. Pharm Res 17:351-357.

13. Zhu G, Mallery SR, Schwendeman SP. 2000. Stabilization of proteins encapsulated in injectable poly (lactide- co-glycolide). Nat Biotechnol 18:5257.

14. Sah H. 1999. Protein behavior at the water/ methylene chloride interface. J Pharm Sci 88: 1320-1325.

15. Prestrelski S, Arakawa T, Carpenter JF. 1993. Separation of freezing- and drying-induced denaturation of lyophilized proteins using stress-specific stabilization: II. Structural studies using infrared spectroscopy. Arch Biochem Biophys 303:465-473.

16. Griebenow K, Klibanov AM. 1995. Lyophilizationinduced reversible changes in the secondary structure of proteins. Proc Natl Acad Sci USA 92:10969_ 10976.

17. Pitt CG, Gratzl MM, Kimmel GL, Surles J, Schindler A. 1981. Aliphatic polyesters II. The degradation of poly (DL-lactide), poly (epsiloncaprolactone), and their copolymers in vivo. Biomaterials 2:215-220.

18. Brunner A, Mader K, Gopferich A. 1999. pH and osmotic pressure inside biodegradable microspheres during erosion. Pharm Res 16:847-853.

19. Fu K, Pack DW, Klibanov AM, Langer R. 2000. Visual evidence of acidic environment within degrading poly(lactic-co-glycolic) (PLGA) microspheres. Pharm Res 17:100-106. 
20. Li L, Schwendeman SP. 2005. Mapping neutral microclimate $\mathrm{pH}$ in PLGA microspheres. J Control Release 101:163-173.

21. Shenderova A, Burke TG, Schwendeman SP. 1999. The acidic microclimate in poly(lactide-co-glycolide) microspheres stabilizes camptothecins. Pharm Res 16:241-248.

22. Dong A, Huang P, Caughey WS. 1990. Protein secondary structures in water from second-derivative amide I infrared spectra. Biochemistry 29: 3303-3308.

23. Krishnan S, Chi EY, Wood SJ, Kendrick BS, Li C, Garzon-Rodriguez W, Wypych J, Randolph TW, Narhi LO, Biere AL, Citron M, Carpenter JF. 2003. Oxidative dimer formation is the critical rate-limiting step for Parkinson's disease alpha-synuclein fibrillogenesis. Biochemistry 42: 829-837.

24. Schwendeman SP, Cardamome M, Brandon MR, Klibanov A, Langer R. 1996. Stability of proteins and their delivery from biodegradable polymer microspheres. In: Cohen S, Bernstein H, editors. Microparticulate systems for the delivery of proteins and vaccines. New York: Marcel Dekker, pp $1-49$.

25. Manning MC, Patel K, Borchardt RT. 1989. Stability of protein pharmaceuticals. Pharm Res 6:903-918.

26. Peters T Jr. 1985. Serum albumin. Adv Protein Chem 37:161-245.

27. Carter DC, Ho JX. 1994. Structure of serum albumin. Adv Protein Chem 45:153-203.

28. Dong A, Prestrelski SJ, Allison SD, Carpenter JF. 1995. Infrared spectroscopic studies of lyophilzation- and temperature-induced protein aggregation. J Pharm Sci 84:415-424.
29. Shenderova A, Ding AG, Schwendeman SP. 2004. Potentiometric method for determination of microclimate $\mathrm{pH}$ in poly(lactic-co-glycolic acid) films. Macromolecules 37:10052-10058.

30. Venyaminov SY, Yang JT. 1996. Determination of protein secondary structure. In: Fasman GD, editor. Circular dichroism and the conformational analysis of biomolecules. New York: Plenum Press, pp 69-107.

31. Mach H, Middaugh CR. 1994. Simultaneous monitoring of the environment of tryptophan, tyrosine, and phenylalanine residues in proteins by nearultraviolet second-derivative spectroscopy. Anal Biochem 222:323-331.

32. Tanford C. 1968. Protein denaturation. Adv Protein Chem 23:131-282.

33. Goto Y, Takahashi N, Fink AL. 1990. Mechanism of acid-induced folding of proteins. Biochemistry 29:3480-3488.

34. Goto Y, Calciano LJ, Fink AL. 1990. Acid-induced folding of proteins. Proc Natl Acad Sci USA 87:573577.

35. Lumry R, Eyring H. 1954. Conformation changes of protein. J Phys Chem 58:110-120.

36. Schulz J. 1967. Cleavage at aspartic acid. Methods Enzymol 11:225-263.

37. Chi EY, Krishnan S, Randolph TW, Carpenter JF. 2003. Physical stability of proteins in aqueous solutions: Mechanisms and driving forces in nonnative protein aggregation. Pharm Res 20:1325-1336.

38. Carrasquillo KG, Stanley AM, Aponte-Carro JC, De Jesus P, Costantino HR, Bosques CJ, Griebenow K. 2001. Non-aqueous encapsulation of excipientstabilized spray-freeze dried BSA into poly(lactide-co-glycolide) microspheres results in release of native protein. J Control Release 76:199-208. 